proceeding to its never ending destination. Vanderkooi, who argued that there is no evidence to account for the process of macroevolution, is probably unaware of the fact that adaptive radiation is responsible for the evolution of higher taxa. True, there are certain forces in nature which cannot be readily explained in terms of science. This inability of science has often been taken up as a proof of the existence of a creator. It is increasingly evident that selection pressures direct the process of evolution. Although it is very difficult to interpret what is exactly a selection pressure, it is not ruled out that a scientist may come out with a model which unearths the hidden secret of selection pressures.

Vanderkooi pointed out that bacterial cells are as complex as any other living cells of the organism, and as such they cannot be considered as the primitive living organisms from which other organisms have been evolved. It is possible that all living organisms might have evolved from some primitive form (monophyletically), and further diversification within the evolved groups might have resulted in the evolution of different groups polyphyletically. The closer resemblance of the amino-acid sequence in cytochrome-C of wheat to that of animals rather than to cytochrome-C of fungi favours the polyphyletic origin.

On the other hand, the concept of creation is nominalistic, and has no place in scientific thinking. The doctrine of creation is a man-made catastrophe, and if it is continued to be advocated by man as a basic conceptual controversy, it is just like putting the clock back and will hamper the advancement of humanity.

To denounce the teaching of the theory of evolution, which has been nurtured by the cumulative efforts of hundreds of scientists for about 100 years, is to deny the legitimate rights of society to learn and understand the reality of the nature and the role of man as part of the natural and social world. If it is done it will become one of the greatest tragedies and educational failures of our time. Yours faithfully, C. R. BABU

Department of Botany,

University of Delhi,

Delhi-7

\section{Use of IS, TWA and ILWS}

SIR,- The present author (PA) is writing to request the increased use in Nature of initial-letter-word-substitution (ILWS). Unpublished studies of the PA show that the superficial-scientific-appearance-rating (SSAR) of a paper is most effectively increased by impersonal style (IS), technical-word- amplification (TWA) and ILWS. There is, moreover, a highly significant positive correlation between the SSAR of a paper and its peer-esteem-rating (PER). The PA hopes that Nature will cooperate in raising the PER of its contributors by encouragement of ILWS, as well as acceptance of IS and TWA. Yours faithfully,

J. M. BARRY

Department of Agricultural Science, University of Oxford,

Parks Road, Oxford OX1 3PF

\section{Between Bees}

SiR,-

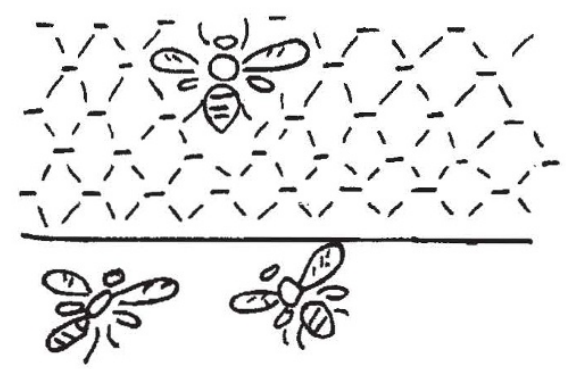

He's saying, "Go to Hive 2 tomorrow.

They're killing bees at Hives 1 and 3". ${ }^{1}$

Yours faithfully,

F. J. MaLoney

Livermore,

California

1 Nature, 241, 171 (1973).

\title{
Obituary
}

\section{Dr Stephen R. Pelc}

Stephen R. Pelc, who died suddenly on February 6 , at the age of 65 , was internationally famous for his pioneer work on the techniques of autoradiography and for his use of these techniques in cellular biological research. He graduated from the University of Vienna and published his first work from the Institut für Radiumforschung in 1931. In 1938 he came to Britain and, after serving in the forces during the war, he restarted his scientific work at the Hammersmith Hospital, London, first as a hospital physicist and then as a member of the MRC Radiotherapeutic Research Unit.

There he began his studies on the action of ionizing radiations on photographic film which led to his development of stripping-film autoradiography for obtaining high resolution autoradiographs of sections of biological material, work done with the enthusiastic collaboration of Dr (now Professor) I. Doniach and under the scientific directorship of the late Dr L. H. Gray.
Dr Pelc had the idea of using pliable photographic film stripped from Ilford stripping plates which were, at that time, being used in industry for other purposes. Kodak then produced the AR10 and AR50 stripping film to his requirements, giving far greater resolution, so that these have now become the standard materials for this form of autoradiography. Initially, when ${ }^{131}$ I was the most readily available isotope, this technique was used by Professor Doniach and himself for studies on the thyroid gland under various physiological conditions. As other radioactive isotopes became available, however, the applications of autoradiography expanded rapidly so that it is now used throughout the world on many varied biological and medical research problems.

$\mathrm{He}$ is most famous for work begun in the early nineteen-fifties with Dr Alma Howard. By incorporating ${ }^{32} \mathrm{P}$ into dividing cells and removing all but the DNA by acid hydrolysis he was able to time the incorporation of ${ }^{32} \mathrm{P}$ into nuclear DNA. He showed that DNA synthesis did not occur after prophase, as had been believed previously from staining evidence, nor did it occur continuously throughout interphase. $\mathrm{He}$ and Howard showed that, for each type of nucleus, there was a particular period of interphase, which he called the "S" (synthesis) stage, during which the DNA content doubled; this DNA was stable and became divided equally into the two daughter nuclei. Before and after the "S" there was a gap in his knowledge of what metabolic processes occurred in the nuclei and, understandably, he named these " $G_{1}$ " and " $G_{2}$ ". The period of interphase therefore could be extended if $G_{1}$ or $G_{2}$ became prolonged. These results were confirmed and extended considerably with the introduction of other isotopically labelled DNA and RNA precursors, particularly those labelled with ${ }^{3} \mathrm{H}$.

Thus he laid the basis for the study of cell kinetics based on the timed uptake of isotopically-labelled precursors and their distribution into the cells derived from the initial, labelled mitotic cell. Of particular importance were his studies on the small intestine, in which 
there is a constant replacement of cells, and on the skin where the processes of keratinization affect the DNA of the daughter cells.

Dr Pelc collaborated with many major research workers in autoradiographic metabolic studies on their own research problems. Thus his own interests extended from DNA over much of metabolic cellular biochemistry. By 1957, however, when he moved to the MRC Biophysics Research Unit at King's College, his main concern had again become DNA. He then showed, in a series of elegant studies, that the DNA of a wide variety of cells was not as completely stable as had been thought originally during the first flush of the DNA-gene concept. His work showed that sometimes as much as 50 per cent of the nuclear DNA was being turned over, the proportion of this "metabolic DNA" in any given nucleus apparently varying with the general metabolic activity of the cell.

For the past two years he was a member of the MRC external staff, working in the Division of Cellular Biology of the Kennedy Institute of $\mathbf{R}$ heumatology in London. Here he extended his work on metabolic DNA, and showed that the metabolic DNA of splenic lymphocytes was considerably stimulated as a result of the immune response. He had also shown that metabolic DNA was of considerable significance in the process of ageing, and was currently very interested in the work of his collaborators, Dr M. Stroun and Dr P. Anker (Geneva) which showed that DNA can be passed from cell to cell. Thus it seemed likely to him that the metabolic DNA, which he saw as the expendable copies of the genic DNA, could act as a messenger between cells and so carry active gene messages to cells in which these genes were otherwise repressed.

Stephen Pelc was an outstanding scientist. A physicist by training, he was a cell biologist first and foremost, who used physics and mathematics adroitly in his biological research. Everyone who knew him was impressed by his gentle, genial kindliness, his readiness to help others and his good humoured philosophical approach to science and to life generally. He was an original thinker who designed his experiments decisively. Thus he was a pioneer, and pioneers rarely get the immediate recognition of their innovations. Sufficient time had elapsed from his development of autoradiography and his work on the timing of the nuclear synthesis of DNA for him to have been recognized as the authority on the techniques and on cell kinetics. The full significance of his discovery of the metabolic turnover of a fraction of nuclear DNA may yet take several years.

Second to science, his major interest was music, in which he found relaxation and mental refreshment. $\mathrm{He}$ was an accomplished violinist and leader of a string quartet which met regularly. $\mathrm{He}$ will be greatly missed by his fellow scientists who relied so heavily on him for his general scientific wisdom as well as for his specialized knowledge.

\section{Announcements}

\section{Miscellaneous}

The following have been elected Fellows of the Royal Society: Professor Percival Allen (University of Reading); Dr Brigitte Alice Askonas,(Immunology Division, National Institute for Medical Research, London); Mr Francis Thomas Bacon (Fuel Cells Limited of Cambridge); Dr Alan Baker (University of Cambridge); Professor Neil Bartlett (University of California at Berkeley); Professor William John Granville Beynon (University College of Wales, Aberystwyth); $\mathbf{M r}$ John Gatenby Bolton (Australian National Radio Astronomy Observatory at Parkes, New South Wales); Professor David Roxbee Cox (Imperial College of Science and Technology, University of London); Professor Leslie Crombie (University of Nottingham); Professor Harry Elliot (Imperial College of Science and Technology, University of London); Professor Douglas Scott Falconer (University of Edinburgh); Professor Geoffrey Alan Gilbert (University of Birmingham); Professor Harish-Chandra (Institute for Advanced Study, Princeton, New Jersey); Professor Richard John Harrison (University of Cambridge); Professor Harold Horace Hopkins (University of Reading); Dr Anthony Kelly (National Physical Laboratory, Teddington, Middlesex); Dr Egon Hynek Kodicek (MRC Dunn Nutritional Laboratory, Cambridge); Professor Jack Lewis (University of Cambridge); Dr Mary Frances Lyon (MRC Radiobiology Unit at Harwell); Dr Peter Bryan Conrad Matthews (University of Oxford); Professor George Francis Mitchell (Trinity College, University of Dublin); Dr Helio Gelli Pereira (Division of Virology at the National Institute for Medical Research, London); Professor Paul Emanuel Polani (Paediatric Research, University of London); Professor John Graham Ramsay (Imperial College of Science and Technology, University of London); $\mathbf{M r}$ Lionel Edward Aston Rowson (ARC Unit of Reproductive Physiology and Biochemistry, Cambridge); Dr Monkombu Sambasivan Swaminathan (Indian Council of Agricultural Research, New Delhi); Dr Jamshed Rustom Tata (Developmental Biochemistry, National Institute for Medical Research London); Dr David Warren Turner (University of Oxford); Professor William Frank Vinen (Univer- sity of Birmingham); Professor Paul Egerten Weatherley (University of Aberdeen); Professor Ronald Whittam (University of Leicester); Professor Alec David Young (Queen Mary College, University of London.

\section{Reports and Publications}

not included in the Monthly Books Supplement

Great Britain and Ireland

Wira. Report and Accounts 1972. Pp. 26. (Leeds Wira, 1973.) Another Kind of Growh the Quality of Life. By Dr Alexander King. 22. (L International Studies, 34 Smith Square, 1973.) $40 \mathrm{p}$.
$[81$ Ordnance Survey. New Forest Tourist Map (Showing New Forest Boundary.) (Southampton:
Ordnance Survey, 1972.) 55p. Philosophical Transactions of the Royal Society of London. A: Mathematical and Physical Sciences. Vol. 273, No. 1234: Large Amplitude Waves in Bounded Media. 1. Reflexion and Transmission of Large Amplitude Shockless Pulses at an Interface. By H. M. Cekirge and E. Varley. Pp. 261-313. London Royal Society, 1973.) £1.40;\$3.90. 181 Building Regulations 1972-General Guidance Note. Building Regulations 1972-General Guidance Note.
Pp. v +26 . (London: HMSO, 1972.) 40p net. 991 The Natural Rubber Producers' Research Associaion. Rubber Development Supplement, 1972, Part Re Rheometer Torque Measurements for the ACS1. By G. M. Bristow. Pp. 22. (Welwyn Garden City, Association, 1972.)
Insight 1 . Insight USA, No, 1, January 1973. Pp. 1-50. Upper Brook Street, 1973.) Department of the Environment. Scottish Development Department, Welsh Office. New Life for 52. (London: HMSO, 1972.) 50p. 52. (London: HMSO, 1972.) 50p.
[121 Murphy Fruit Grower's Book. Pp. 60.
Murphy Nurseryman's Book. (Wheathampstead, Herts: Murphy Chemical, Ltd. 972.)

Griffin and George, Ltd. Apparatus for New or Expanding Laboratories. Pp. 53. Apparatus and Chemicals for the Nuffield Cumbined Science Course. 5.13 Project. Ap 13. Apterials for the Science for the Scottish Integrated Science Course. Pp. 25. Griffin Srotsh integrated Science Course. Pp. 25. (Wembley: Griffin and George Limited, 1972.) [121 New Technologist: a Development Action Guide for Workers in Science and Technology. Pp. 16. (London: Voluntary Committee on Overseas Aid and Development, International Development Centre, 25 Wilton Road, 1973.)
Proceedings of the Royal Irish Academy. Vol. 72. Proceedings of the Royal Irish Acras of Operators with Closed Convex Numerical Ranges. By G. De Barra. Pp. 149-154. 12p. Vol. 72, Section A, . actions of the LondonYol 72. Section B, No. 20: The Structure of the Vol. 72, Section B, No. 20: The Structure of the Doville, Eastern Inishowen, Co. Donegal. By J. C. Moville, Eastern Inishowen, Co. Donegal. By Section B, No. 21: Some Brown Podzolic Soils in the West and South-West of Ireland. By M. J. Conry, F. De Coninck, J. Bouma, C. Cammaerts and $J_{\text {. J. Diamond. Pp. 359-402 + plates 15-17. }}$ 80p. Vol. 72, Section B, No. 22: An Appraisal of Densities. By D. A. Morton-Blake. Pp. 403-414. 18p. Dublin: Royal Irish Academy, 1972.)
University of Glasgow. The Hannah Research Institute for Studies Relating to the Production and Utilization of Milk. Report for 1972 . Pp. $64+5$ tute, 1973.) Journal of Nonmetals, Vol. 1, No, 1 (1972) Smolichowski. Pp. 1-96. Subscription Rates (Pe Volume Postpaid) 4 Issues per volume Libraries: US/Elsewhere, $\$ 50$; $£ 20.85$; Great Britain $£ 19.60$ Individuals (who warrant the journal is for their own use and order direct from the publisher), USA/ elsewhere $\$ 14.50$; $£ 6$; Great Britain $£ 5.50$. (London and New York: Gordon and Breach, Science Publishers, 1972.)

Ordnance Survey. Professional Papers New Series No. 25: The Overhaul of the 1:2500 County Series Maps. Pp. 30+9 figures. (Southampton: Ordnance Survey, 1972.) $£ 1.75$. Port Erin, Isle of Man. Annual Report No. 84 fo Aniversity Press, 1972.) Department of Education and Science. EducaSchools for Delicate Children, Special Classes in 